\title{
FROM CHURCH TO STATE: THE QUEENSLAND GOVERNMENT TAKE-OVER OF ANGLICAN MISSIONS IN NORTH QUEENSLAND
}

\author{
Noel Loos
}

In 1886 the Griffith Government in Queensland began a policy of supporting Christian missions to Aborigines which subsequent governments continued so that Queensland provided much more support to missions than any other government in Australia until the second half of the twentieth century. ${ }^{1}$ This meant that the Queensland Government and the churches entered into a partnership through the various missionary bodies. The churches thus became important arms of government policy. Increasingly, the advantage of this system was with the government which obtained an Aboriginal social service and control agency on the cheap. The Lutherans, Presbyterians, Anglicans, and Brethren established twelve large missions in remote areas of North Queensland, ten of which still exist, under the 1984 Deeds of Grant in Trust legislation, as self-governing Aboriginal Communities.

The Anglican Church, through its constitutionally appointed mission agency, the Australian Board of Missions (ABM), and in conjunction with the local dioceses, founded four of these missions: Yarrabah (1892), Mitchell River, now Kowanyama (1906), Lockhart River (1924), and Edward River, now Pormpuraaw (1938). Yarrabah is in the Diocese of North Queensland; the other three missions are in the Diocese of Carpentaria. ABM also supported Forrest River Mission in Western Australia, founded in 1913, and a number of chaplaincies. In 1915, it accepted the Torres Strait Mission from the London Missionary Society and converted it to the Anglican rite. The story of the Torres Strait Island Mission is very different from the missions established for Aboriginal people and will not be discussed in this paper. Nor was the Torres Strait Island Mission involved in the take-over with which this paper is concerned.

The transfer of administrative and financial responsibility from the Anglican Church to the Queensland Government was an epiphanal event, in that it brought to the surface many issues underlying Anglican missionary policy and practice, the relationship between church and state, and the relationship of both with the Aboriginal people through the 75 years of Anglican government. Significantly the Aborigines who grew up on missions were thought of, and referred to, as 'inmates' until the end of this missionary era.

The Australian Board of Missions (ABM) is the missionary agency of the General Synod of the Anglican Church of Australia. It attempts to co-ordinate missionary outreach within Australia and overseas on a nationwide scale and to educate Anglicans about what ABM sees as their missionary responsibilities. Since its establishment in 1850 it has emphasised its special responsibility to support Aboriginal and Torres Strait Islander ministries within Australia. In the 1980 s almost one-third of the mission grants were still

Dr Loos is Associate Professor in the Department of History and Politics at James Cook University.

Australian Board of Missions (hereafter ABM) Board Minutes, 'Report on Aborigines of Australia and the work being done for them by Government and Missionary Bodies', 2021 November 1940:4-5; Hann to Robinson, 28 March 1950, ABM Chairman's Correspondence, Personal file: Alice Hann. 
directed to Aboriginal and Torres Strait Islander ministries. The Diocese of Carpentaria, whose cathedral is at Thursday Island in the Torres Strait, received almost two-thirds of the Aboriginal and Islander Mission Grant. 2

Although periodically the Board at the national office in Sydney reflected seriously upon the implications of its continued administration of the Aboriginal communities created by its missions, the decisions to end this state of affairs were taken in the remote dioceses responsible for their day to day running. There the decisions were based on insufficient funds, inadequate government support, and the difficulty of staffing the various mission villages. In the case of Forrest River, supervised by now by a subcommittee in Perth, the conclusion was reached that, after over fifty years, the results were not worth the effort. Indeed, the inability of $\mathrm{ABM}$ to institute major changes in mission philosophy and practice, as indicated by the failure of the Aboriginal Christian Co-operative Movement, stands in sharp contrast to the growth in social awareness that is evident in Sydney. ${ }^{3}$

A number of reports on the Forrest River Mission were made after World War II which confronted the Australian Board of Missions with the problems inherent in the paternalistic control of Aborigines that had been developed in earlier decades. These have been referred to in this study because they illustrate so graphically the general situation that applied for all ABM missions, despite the differences between them. Bishop Cranswick, Chairman from 1942 to 1949 , is nowhere near as dominant a figure in the history of ABM as his predecessor, Canon Needham. However, his comments about the historical experience of Aborigines and the responsibilities resting upon white Australians for their future suggested that the 'new age' in mission history he referred to had dawned, even for Aborigines. ${ }^{4}$

In his instructions to the new Chaplain-Superintendent at Forrest River, the Rev.Keith Coaldrake, he attacked negative stereotypes, elaborated upon the richness of Aboriginal culture and the poor treatment Aboriginal people had previously received. He suggested surprising models, the camps organised for Aborigines by the army in the Northern Territory. Here they experienced 'security and fellowship, community life, and attention to diet and health' in contrast to their previous existence on missions and government settlements. While still reflecting the contemporary ethnocentrism, he insisted: 'It is for the natives to choose whether they will accept ... a better way and truer belief ... or will modify their own codes and belief, or will build up some blend both Christian and native'. The missionaries had to be 'fulfillers and not destroyers of the ancient law of the Aborigines to help these men and women left over from the stone age to survive and prosper in that contact with our advanced civilisation that has now become inevitable'. 5 Although these instructions are still clearly daubed with ideas from the past, there is no escaping the more enlightened vision, much of it still considered new and challenging over forty years later. While still maintaining the importance of the missionary role, he admitted mistakes had been made in the past and that methods had sometimes been unsatisfactory. His lengthy 'Instructions' codified as 'The aim and policy of the Australian Board of Missions' concluded with the challenge that all involved in the missionary task had to ask from year to year: 'What is it we are really trying to do?'

2 ABM 1984; ABM 1986; Partners February-April 1990.

3 Loos and Keast forthcoming.

4 Cranswick to Eileen Heath, 5 December 1945, ABM Chairman's Correspondence, Personal file: Eileen Heath; ABM Board Minutes, 'Chairman's Report', 28-29 July 1948.

Instructions issued to the Rev. Keith Coaldrake on the occasion of his assumption of the office of Priest-Superintendent of the Forrest River Mission', 19 February 1948, ABM Chairman's Correspondence, Series 6, Box 2, Folder 10. 


\section{THE QUEENSLAND GOVERNMENT TAKE-OVER OF ANGLICAN MISSIONS}

There are many other examples of the growing social awareness in Sydney of the problems confronting Aboriginal people in Australian society. Archdeacon Robertson, Chairman from 1949 to 1956 , was clearly aware that missions had to contend with an Aboriginal response that was at least in part conditioned by colonisation. He wrote to Sister Delaney soon after her arrival at Mitchell River Mission:

They do not take discipline easily and it is very hard to change a nation of people who have been almost slaves into a nation of free people. We gave them such a bad time in the early days, we have been giving them such a bad time since ...6

In 1966 Canon Frank Coaldrake, Chairman from 1957 to 1967, challenged his Board and supporters of ABM to support the struggle for Aboriginal citizenship rights. "The citizen's rights of the Aborigines and Torres Strait Islanders in the State of Queensland have long been defective. ... The Church in Australia should not ignore the fact that so many Australian Anglicans are being kept in a condition of bondage'. ${ }^{7}$ Earlier, in 1960 , he had informed the Board that the 6,000 Torres Strait Islanders were 'Anglicans in poverty Anglicans in bondage' 8

$A B M$, in association with the Diocese of Carpentaria, unsuccessfully sought permanent tenure of reserve lands, not only at Lockhart River for the Co-operative, but also at Mitchell River where the diocese was developing the Carpentaria Aboriginal Pastoral Company. The Queensland Government even rejected a proposal to allow Aborigines on Anglican missions to buy and own their own homes because it suggested a permanent Aboriginal presence that the Government could not contemplate. ${ }^{9}$ Increasingly, ABM found that its plans for Aboriginal people on its missions were in conflict with Queensland Government policy: 'To be in control of himself, his family and his property he [the Aboriginal] must be exempted from the Act'. But if he gained exemption he was not allowed to live 'among his own people, in his own country'.10 ABM found itself caught up with other churches, especially those involved in Aboriginal missions, in an exploration of what legal right Aborigines had to their land, an investigation that resulted in the Australian Council of Churches' support for land rights and compensation for the loss of land. ${ }^{11}$

There was also an awareness of internal contradictions in mission policy and practice. From the beginning a caste system had been created of white missionaries and Aboriginal people that was manifested in the siting of the missionary residences apart from those of the Aboriginal Christians within the mission compound. The camp for visiting Aborigines and those who had not accepted mission authority or been accepted into it was completely outside the compound at a distance where each group could maintain a separate existence with a minimum of disturbance. While the missionaries thought of themselves as the ones who were being shielded from the noise and life style of the camp, it is equally clear that the camp Aborigines derived a similar benefit.

The caste system, however, extended well beyond the geographical placement of the living quarters. The quality and size of the missionaries' living quarters, while often

6 Robertson to Sister Delaney, 21 March 1951, ABM Chairman's Correspondence, Personal file: D. Delaney.

7 ABM Board Minutes,'Chairman's report', 3-5 May 1966:10.

8 Ibid., 27-29 September 1960.

9 Ibid., 11-13 April 1961.

10 ABM Board Minutes, 'Carpentaria Mission studies', 11-13 April 1961.

11 ABM Board Minutes, 'Report from division of mission of the Australian Council of Churches 1964-5', 26-28 October 1965. 


\section{ABORIGINAL HISTORY 1991 15:1}

extremely primitive compared to what was the norm in white Australia, reflected the superior caste the whites assumed within the mission community.

A number of reports were made on the perpetually troubled Forrest River Mission in the late 1940 s and 1950 s when closing the mission was seriously being considered. They emphasised the contradictions posed by the caste system within missions. The Rev. R.B. Cranswick pointed out that the ration system of payment not only made mission inmates into beggars, but also discouraged them from working. They were obviously passively resisting the 'prison-like discipline which seemed to be enforced for its own sake and with little apparent reason'. He pointed out that it was on the spiritual side that the mission had been able to do least because of this guard-inmate situation and that the Aborigines have seen little of what Christianity is, and therefore are not attracted'. They were made to feel their inferiority not only at every meal, but even on a picnic as one at Forrest River dramatically demonstrated:

They see white people keeping all the best for themselves and have become accustomed to expect it of us. Scraps of food left on the plates of the staff are eagerly sought for. During the first week of my visit to the mission we went to Camera pool. At meal time they made our fire, got us improvised seats and saw us sit down to turkey and tinned fruit, having already carried everything necessary all the way. They then went away elsewhere to a meal of damper and tea. There seems to be a very definite feeling of inferiority on their part.

He pointed out that 'the prison-like discipline' had created 'an atmosphere of suspicion and mistrust in which it is impossible to do much Christian work', and that 'corporal punishment, chaining of natives and punishments which show a complete lack of respect for native customs, seem to have been the rule back to the early days of the mission'. This regime had been so internalised that Aborigines who were given some authority thought this was the only way to run a mission. One said: 'I owe what I am to the thrashings $\mathrm{Mr}$ .... gave me'. In the 1970s and 1980s, some older Aborigines made comments about the 'civilising', Christianising effects of the dormitory system at Yarrabah. Cranswick also pointed to the ultimate contradiction in mission policy. It aimed at creating a new spiritual understanding by denigrating and disallowing the expression of Aboriginal spirituality: 'The native customs seem to provide endless opportunities on which to build Christian teaching, but we have shown a lack of respect for these'.12

There was also an awareness by the end of World War II that the missions were going nowhere. With the exception of Edward River, the first stages of the evangelisation process had been completed. All Aborigines in the mission compound were now baptised and, if old enough, confirmed as Anglican Christians. Their understanding and commitment to their faith varied probably as much as that within any parish in the suburbs. Keith Coaldrake had felt the need to state this in his report to the Board and to his Perth Committee:

The exact nature of the spiritual work here is, I think, not understood by most people. Briefly, the period of its foundation is now part of the history of this Mission, and the place functions more as an isolated country settlement today. Likewise, the period of purely evangelical preaching and teaching on a very

12 'Report on Forrest River, July to December 1947', ABM Chairman's Correspondence, Personal file: R.B. Cranswick. Rev.R.B. Cranswick should not be confused with Bishop G.H.Cranswick, Chairman of ABM, 1942-1949. Aborigines at Yarrabah made this comment in discussion with me on visits to Yarrabah in the early 1970s. In 1989, two of my Aboriginal students interviewed older relatives about he dormitory system and found that the three women they interviewed presented the complete spectrum from strong approval to bitter disapproval. 


\section{THE QUEENSLAND GOVERNMENT TAKE-OVER OF ANGLICAN MISSIONS}

elementary level, and the proselytising of heathen primitives has passed and we now deal with natives who have most had lifelong Christian teaching and influence. Most of the teaching is on the Sunday School level. ${ }^{13}$

Professor Elkin, an ordained Anglican priest himself, was nowhere near as complacent about this level of achievement: 'Our Church services and bell-ringing are all of a piece with the general routine we have introduced. The Compound is a boarding-school from which only death, or perhaps old age, will release its inhabitants'. ${ }^{14}$ The boarding-school label could be applied to all missions and government reserves where entry and departure were controlled. Elkin pointed to the self-perpetuating apathy these closed institutions had generated:

The young men of 1928 are still lining up daily to be allotted their tasks, having become specialists in nothing, having no sense of independence, having no money or other exchange-economy through which to express themselves in satisfying physical and mental needs. And all they can look forward to is a parasitic old age, probably out in the Camp. ...when they should be in their prime, as leaders of social groups, they are leading an aimless existence; unpaid workers on a Mission which, outwardly at least, gets nowhere...

He said this of Forrest River, but it applied to nearly all missions and government reserves at this time and for decades after: 'We are the cause of the apathy and penury of the people, and we ought to do something about it'.15

Elkin's solution was starkly simple and reflected his own limited expectations for Aboriginal people: to learn from the Queensland Government and, as a consequence, to provide a much more expensive infrastructure and spend a great deal more each year. As he pointed out: 'The work in hand is to run an institution of a peculiar kind - the building up of a community'.16

Consequently, by the $1950 \mathrm{~s}$, the Board had been confronted by the sociological and religious contradictions and problems inherent in governing Aboriginal communities 'to maintain a work,' as its Executive Officer, Rev. M.A. Warren, said, 'which only in its minor aspects could be called evangelistic'. 17

Yarrabah, like Forrest River Mission, was beset with administrative problems from its inception but there was soon a great deal more to show for it. A sizeable mission village of over 800 people developed to which the Queensland Government was only too happy to send Aborigines it considered in need of such confinement, more so than to any other Queensland mission. There was conflict with the Queensland Government because it considered the Church gave too little attention to the industrial side of the mission and too much to the religious, especially because of its failure to make the mission anywhere near self-supporting. The Government was also drawn into the conflict within the Anglican Church over the administrative control of Yarrabah.

Although within the Diocese of North Queensland, Yarrabah had been administered from its beginning in 1892 by the Sydney based Executive Council of ABM because North

'Report for year July ' 52 to June '53', ABM Chairman's Correspondence, Forrest River Mission.

14 ABM Board Minutes, 'Report on Forrest River by Professor Elkin', 13-14 November 1946.

15 Ibid.

16 Ibid.

17 ABM Board Minutes, 'Aborigines: Forrest River Mission', 26-28 July 1955. 
Queensland was unable or unwilling to assume responsibility. The Bishop of North Queensland was responsible for overseeing its spiritual life. Like the Diocese of North West Australia, North Queensland was a poor, struggling diocese in a vast, sparsely populated region. In 1910, when the Queensland Government objected to dealing with a New South Wales committee, an administrative committee was set up in Brisbane with the Archbishop as Chairman. This situation persisted until 1937 when Bishop John Oliver Feetham of North Queensland gained administrative control for his diocese after a bitter campaign that began in 1929.18 The correspondence contains serious allegations by Feetham of poor management and some agreement from $A B M$ that it was in need of improvement. Subsequent events suggest that the North Queensland Diocese was incapable of meeting the challenges implicit in governing a mission community.

From 1948, the Queensland Government put pressure on the Yarrabah Committee to improve living conditions on its mission and was in turn challenged to provide more adequate financial support because the Church was doing government work. Even after receiving a grant of 25,000 pounds, the Yarrabah Committee considered it would have to hand over the reserve to the Government unless it received more adequate support. The Government met all Yarrabah's accumulated debt in return for a position on the Committee. It was still much cheaper to retain church involvement than to take on full responsibility. 19

The difficulty of finding and retaining suitable staff had always been a problem at Yarrabah, as at all of ABM's Aboriginal missions. In 1952, the decision was made to employ Anglican Church Army officers as superintendents. Their discipline, training, and commitment to evangelism and service led them to set high standards for themselves and to aim at a similar response in the people they ministered to. This had proved attractive to some Aboriginal people at Palm Island and Yarrabah and a small number entered the Church Army training college at Newcastle. Some of these graduated and eventually worked among their people. Bishop Arthur Malcolm and Sister Muriel Stanley of Yarrabah and the Reverends Alan and Norman Polgen of Palm Island owed their Christian formation to the Church Army example and training. ${ }^{20}$ However, many Yarrabah Aborigines objected to the greater demands the Church Army officers made upon the labour force and to the increased penalties they imposed upon those offending against mission rules. Eventually, in 1957, the Yarrabah Aborigines staged a strike to protest against their inadequate rations, poor working conditions, and the autocratic rule of the superintendent.

In retrospect, it seems that the Church Army officers, at that time unfamiliar with the aspirations and problems confronting Aboriginal people,were trying to impose the strategies of the 1930s and 1940s upon a people who were increasingly aware of what was normal and acceptable. In 1956, 86 men and women were employed outside the mission. By this time, contact had been made with the trade union movement and some union officials were becoming concerned at the living conditions on Aboriginal communities. The

18 ABM Board Minutes, 'History compiled from official documents in the possession of the Board concerning the relationship of the Bishop and Diocese of North Queensland, the Australian Board of Missions and the Yarrabah Mission', 13-14 March 1935; ABM Board Minutes, 'Chairman's report: Yarrabah', 14-15 April 1937. The correspondence of this struggle is contained in 'ABM Chairman's Correspondence: Yarrabah'. Craig 1980: 75-7.

20 Discussion with Bishop Arthur Malcolm at Yarrabah during 1988 and 1989 and interview at Townsville, 10 November 1989. Sister Muriel Stanley was a trained nursing sister, but 'Sister' was also the title given to female Church Army officers. Male graduates were referred to as 'Captain'. 
development of the vast bauxite deposits at Weipa, a Presbyterian mission, inevitably focused the attention of the relevant trade unions on all the Cape York Peninsula missions. 21

The Superintendent, Captain Wilcox, with the support of the Queensland Government, expelled three leaders of the strike. Approximately 200 residents of Yarrabah, many of them supporters of the strike, were quickly given exemption from the Queensland Act and left the mission over the next two years. This massive increase was justified as part of the policy of assimilation. Yarrabah seemed to settle down. A social welfare committee, similar to those on Government settlements, was formed to involve staff and Aboriginal residents; rations were increased; more attention was given to health; more trained teachers were employed; and farming was expanded with the assistance of the Department of Native Affairs. ${ }^{22}$ However, when the Minister, Dr Noble, and the senior officers of the Department of Native Affairs, Con O'Leary and Pat Killoran, visited Yarrabah in late 1959 they were shocked at the condition it was in. They confided to John Warby when they moved on to Lockhart River that Yarrabah was a 'headache'. They needed to spend 250,000 pounds on improvements and would not commit such a large outlay on a non-government settlement. Perhaps, even more worrying was the rowdy resentment expressed at a community meeting that lasted till 2a.m. that O'Leary and Killoran attended. The Aboriginal residents kept 'interrupting and shouting out that the Superintendent was a liar etc etc'. Noble was also concerned at the conditions the people at nearby Bessie Point were living under, many of whom had left Yarrabah in the previous two years. Noble considered the treatment of the Bessie Point people 'a disgrace'. They were forced to consider proposing to Bishop Shevill that the Queensland Government take over the administration of Yarrabah. ${ }^{23}$

By this time, the Townsville Committee and ABM had had enough, even though the government was by then contributing 50,000 pounds per year to Yarrabah's upkeep. The Superintendent reported in the diocesan yearbook: The Church at Yarrabah is no longer running a mission but a large Social Service project beyond the financial and manpower resources of the Church'. ${ }^{24}$ After a decade of propping up the mission to avoid the inevitable, the Queensland Government took over administrative and financial responsibility on 1 July 1960, even paying the Chaplain's salary. The Church of England was guaranteed that no other religious denomination would be allowed access to Yarrabah. Until there was a schism among Aboriginal Christians in 1990, St Alban's Anglican Church was the only one in the community.

In 1960, no one expressed the view that the Diocese of Carpentaria missions should also be handed over to the Government. After a special visit to the three Aboriginal missions in which he saw the desperately poor conditions under which the Aborigines and

21 Quensland Parliamentary Papers (hereafter Q.P.P.) 1956-7, II:1250; F. Thompson to Clint, 19 January 1958, ABM Chairman's Correspondence, Series 14; Interview with Fred Thompson, 17 December 1990; Warby to Bishop of Carpentaria, 7 October 1959; Clint to Coaldrake, $20 \mathrm{March} 1957$, ABM Chairman's Correspondence, Series 13; Robertson to Clint, 23 August 1955, ABM Chairman's Correspondence, Personal file: Alf Clint.

22 'Native affairs report', Q.P.P. 1958-9, II:1060-1 and Q.P.P. 1959-60, II:1160-1; Q.P.P. 1959-60:1189.

23 Warby to Bishop of Carpentaria, 7 October 1959, ABM Chairman's Correspondence re Aborigines, Series 14.

24 Diocese of North Queensland, 1959:61; ABM Board Minutes, The Future of Aboriginal reserves', 27-29 October 1959. 
missionaries lived, the Chairman, Frank Coaldrake, was optimistic for the future. He had confidence in the Diocese, the wealth of natural resources of the region, and the goodwill of the Aborigines at Lockhart, Mitchell, and Edward River Missions. If ABM had been able to draw more upon the resources of the Queensland Government or had the capital of multinational companies like Comalco or BHP, Coaldrake's optimism might have been justified. 25

The new Bishop, John Matthews, had earlier visited the Diocese and was appalled at the state of the missions. He had then taken up a senior appointment in Carpentaria before being consecrated Bishop. In 1961 he reported that the three missions were 'almost at the point of disintegrating' because of lack of staff and the pressure on those working there. 'It does not look as if the Church in Australia is vitally interested in this work', he wrote, echoing the cry missionaries had uttered during the previous 100 years. ${ }^{26}$

The first indication that the Bishop of Carpentaria might seek a radical solution to the problems confronting his missions surfaced the same year when he suggested moving Lockhart River Mission 50 kilometres to be closer to Portland Roads wharf and Iron Range aerodrome, a plan the government was ready to agree to. This plan was then abandoned. With the collapse of the Lockhart River Aboriginal Christian Co-operative, the future of the mission looked so difficult that in 1962 consideration was given to moving the whole community to Edward River and Mitchell River missions, provided 'the consent of the people concemed is freely given:27 After discussions with the Queensland Government in which he had requested greatly increased Govemment subsidies to Carpentaria missions, he suggested that the people be moved to the government settlement of Bamaga at the tip of Cape York Peninsula where they would have much better food rations, educational and medical facilities, employment prospects and housing than the Church could supply. They would thus have become the Government's administrative and financial responsibility. All of these suggested shifts were over distances of approximately 300 kilometres. Fifty people from Lockhart River were persuaded to move to a village at Bamaga which was given the Lockhart River name, Umagico. The rest of the community soon made it clear that they did not wish to move. The decision was then made to relocate the village in the mission reserve near Portland Roads wharf and the airport, as first planned. There, in its present site, it was at least much easier to service.

By this time, Bishop Matthews had concluded he could not get adequate funding from the Queensland Government to run the missions satisfactorily. Aborigines and missionaries would have had to continue to exist in deplorable, degrading conditions with substandard services beyond the means of the Diocese or $A B M$ to improve. Consequently, with the support of ABM, he decided upon the transfer of all of the Aboriginal missions in Cape York Peninsula to Queensland Govemment administration. The takeover of Lockhart River, Mitchell River, and Edward River Missions occurred on 1 May 1967.28

25 ABM Board Minutes, 'Special visit to the Diocese of Carpentaria by the Board's representatives', 27-29 October 1959.

26 Matthews to Coaldrake, 28 August 1961, ABM Chairman's Correspondence, Personal file: A. Lupton. The letter referred enthusiastically to Lupton. Telephone discussion with Bishop A. Hall-Matthews, 18 March 1991.

27 ABM Board Minutes, 'Missions Commission', 1-3 may 1962; 'Memorandum on the removal of Lockhart River people: Chairman's response to the Board', 23-25 October 1962.

28 Hudson to Director of Native Affairs, 30 June 1961; Memorandum of interview of Minister of Health and Home Affairs with Right Reverend S.J. Matthews, 30 June 1961, 


\section{THE QUEENSLAND GOVERNMENT TAKE-OVER OF ANGLICAN MISSIONS}

When the removal of Lockhart people was considered in 1962, Coaldrake emphasised that all associated costs would have to be borne by the Queensland Government and that, in the new situation, the Church would only exercise a pastoral ministry. The Yarrabah model was fresh in his mind. 29

There were a number of other factors that supported the conclusion that the administration of the missions should be transferred to the Queensland Government. Diocesan concern extended well beyond the Bishop. A number of reports in the early 1960 s had indicated how deplorably inadequate the communities were in terms of food, housing, clothing, sanitation, mission development and maintenance. One submitted to the Board by the Superintendent of Edward River, Gordon Green, finished with a section headed in bold capitals: "THE CONTINUING DISGRACE OF ABORIGINAL LIVING STANDARDS AND LACK OF REASONABLE IMPROVEMENTS ON ABORIGINAL MISSIONS'. Green urged the Church to 'make public the scandalous conditions on these missions' unless the Government quickly remedied their secular aspects. However, he sheeted home the responsibility to the Church for being so pusillanimous in its dealings with the government. ${ }^{30}$

In addition, by 1966, Church and Government administrators had accepted the inevitability and the logic of the transfer. In February 1964, the cyclone 'Dora' had destroyed Edward River and Mitchell River Missions. The Government had accepted the responsibility of rebuilding the two townships at standards comparable to government settlements, a task clearly beyond the Anglican Church. ABM began a Special Appeal reaching out ecumenically beyond the Anglican Church within Australia and overseas through interchurch aid, raising a 'generous' $\$ 84,000$, which was enough at least to rebuild the church in each community. Thus the Government was involved in rebuilding, and with Lockhart River, resiting all of the Anglican missions in the Diocese of Carpentaria. By this time, the 'goodwill' of the Aborigines on these three missions was wearing thin. Many worked outside the missions and were increasingly aware of how poor their conditions were and how bleak was their future. The Chairman reported in 1966: 'In these two areas [Cape York Aboriginal missions and the Torres Strait Mission] there has been much unrest as the people's expectations rise'. ABM was unable to meet the expectations or to persuade the Government of their urgency. The Government's response to ABM's request that it take responsibility for the schools had met with a slow and hesitant acceptance. Finally, ABM accepted the impossibility of staffing the Cape York missions. There were always important positions vacant and a rapid tumover. Few staff lasted longer than the initial twoyear term, many not even that long. Where ABM could expect a missionary to serve five or ten years in other places, in Carpentaria they could be burnt out in two years, thus

Queensland State Archives, Health and Home Affairs 6694 N.A. of 1961; Coaldrake to Matthews, 16 December 1965, Diocese of Carpentaria Papers, Oxley Library; ABM Board Minute, 'Chairman's report', 27-29 April; 'Memorandum on the removal of the Lockhart River people', 23-25 October 1962; 'Chairman's report', 3-5 May 1966; 'Chairman's report: future of Cape York Mission', 25-27 October 1966; 'Chairman's report: Cape York transfer', 4-6 April 1967.

ABM Board Minutes, 'Memorandum of the removal of Lockhart River people', 23-25 October 1962; 'Standing Committee: transfer of Cape York Missions to Government', 25-27 October 1966.

30 ABM Board Minutes, 'Report on full situation at Edward River Mission', and 'Report on Mitchell River Mission to the Lord Bishop of Carpentaria', 11-13 April 1961. Green was familiar with the three missions. 
magnifying greatly the recruitment problem. "There is no greater challenge to sacrificial services anywhere in the Church', the Chairman, Frank Coaldrake, lamented. It was part of the challenge that finally had beaten the Church. ${ }^{31}$

On 15 September 1966, The Minister for Education and Aboriginal Affairs met with the Bishop of Carpentaria and the Chairman of ABM and agreed that the transfer of the three Cape York Anglican Missions should occur as soon as practicable to make available greater resources for their management. The Bishop and the Minister agreed 'that this would be a transfer of management but that Church and Government would continue in partnership to serve the interests of the Aboriginal people'. The Anglican Church was left with its religious monopoly of the three missions for at least the next ten years. It was still intact in 1990.

The Board and the missionaries in Cape York were very much aware that, when the Queensland Government had taken over the Presbyterian Mission at Mapoon in 1963, it had been closed down and the people moved, some by force, to Bamaga. In 1966, Weipa was taken over by the Government and a large part of the Aboriginal reserve cancelled and thrown open for the mining of bauxite by Comalco. The Bishop was assured that the Government would maintain the three Anglican Aboriginal Reserves at their existing extent and that the cattle, stock and plant would be vested in the Aboriginal Welfare Trust, thus assuring ABM that profits from the very large herds of cattle that the Diocese had built up would not be used instead of Government expenditure. The Board noted that the transfer was part of a 'general trend to transfer missions to Government control throughout Australia'.32 In Queensland, beginning with discussions over Yarrabah in 1950, the ABM missions had initiated the trend with a reluctant Government.

The concept that underpinned all of the negotiation was assimilation, sometimes expressed with such frankness that it seemed to be assimilation gone mad. The degree of social engineering that was contemplated with well-intentioned equanimity was breathtaking. 'The training of Aborigines in the development of skills which will enable them to take their place in the general community is the avowed aim of government programmes,' Frank Coaldrake observed in 1962. 'This must mean the eventual movement of Aborigines from Cape York into southern townships and rural areas', except for the aged and incapacitated who would be institutionalised in their mission locality and a small number who could find employment in the few projects, being developed in the Peninsula, most associated with mining. Consequently, it was seen to be no great hardship for most Lockhart River or Yarrabah people to be transferred to other areas if that was necessary. Coaldrake believed that eventually 200 of the 300 Lockhart people 'could be ready for absorption into the general community in the South'.

It is clear that at this time, for the Government and the Anglican Church, the rebuilding of Edward and Mitchell River communities and the resiting and rebuilding of Lockhart River were but temporary expedients until Aboriginal reserves ceased to be needed. By 1967, confronted with the reality of the closure of Mapoon and the transfer of its people, and the reduction of Weipa Reserve to a fraction of its original size, the Church had realised that the rights and wishes of the Aborigines deserved greater consideration.

The Board had formulated its policy with regard to Aboriginal reserve land in 1959 in association with the ecumenical National Missionary Council. It stipulated 'security of land

31 ABM Board Minutes, 'Chairman's report: Aborigines', 3-5 May 1966.

32 ABM Board Minutes, 'Chairman's report: future of Cape York Missions' and 'Standing Committee: transfer of Cape York Missions to Government', 25-27 October 1966. 


\section{THE QUEENSLAND GOVERNMENT TAKE-OVER OF ANGLICAN MISSIONS}

tenure for residence and economic enterprise must be provided for Aborigines and Missions in Reserves'; and

Australia's honour demands that Aborigines be considered for preferential treatment concerning any use of reserve lands ... In the case of unexempted, or backward persons, such rights should vest in trustees or guardians on their behalf. Such provisions are an integral part of any assimilation process.

The stand was clear despite the ethnocentric paternalism starkly evident in its expression. As the Anglican Church prepared to divest itself of its missions with, in retrospect, a somewhat indecent haste, Coaldrake asked his Board:

should the Church respect the people's wishes and uphold them, even if the Church is convinced of the ultimate need for the things planned by the Government. 33

To its credit, the answer was given in the affirmative.

By allowing the Government to take over the four missions in North Queensland, the Church performed an extraordinary miracle, a twentieth century example of the loaves and fishes. Resources that it had begged for for so long began instantly to appear. Plans were made to rehouse completely the residents of Yarrabah in 120 new houses. Twenty were occupied within a year of the take over, part of a massive building program which would transform Yarrabah. Milk and vitamins were provided for the children and trained teachers improved the standard of schooling. Trained staff worked in Maternal and Child Welfare clinics, and hygiene, education, nutrition, indoor plumbing, and sanitation programmes were developed to make Yarrabah a healthier place. Powdered milk, Farex, Baby Rice, Vegemite, peanut paste, cheese, Hypol and fruit, common enough in Cairns but luxuries in Yarrabah, were made available to young children. Electricity was introduced and Yarrabah fully electrified by 1965 . A new primary school was constructed and taken over by the Queensland Education Department in 1962.34 At Edward River and Mitchell River, the extensive rebuilding programmes had begun in 1964 after cyclone 'Dora'. After the take-over in 1967 the provision of services and amenities was similar to that at Yarrabah. At all missions a cash economy replaced the previous ration and mixture of ration and cash economies that the missions had used. 35

The miracle the Church had wrought was, of course, the necessary effort and expenditure the Government needed to bring these communities up to the same standard as the other Aboriginal reserves at Bamaga, Palm Island, Cherbourg, and Woorabinda. The effort devoted to hygiene, sanitation, diet, reticulated water, and community health programs reflected the need to raise the health of the community. The Government was attempting to meet the minimum standards on Yarrabah and the other missions now that it was responsible and not the Church. Yet the standards of housing, diet, clothing, education, and community health were well known from Government inspections. In the $1920 \mathrm{~s} 90 \%$ of Yarrabah Aborigines had been infected with hookworm; $80 \%$ were reported suffering from skin diseases in the 1930s. In 1938, the anthropologist, Norman Tindale, had reported the rations were 'only enough to prevent starvation'. In 1935 Dr Raphael Cilento, a Government medical officer, had reported that the diet was 'entirely lacking in vitamins', and represented 'an actual menace to healthy development'. The Government had criticised the

33 ABM Board Minutes, 'Chairman's report to the Board: memorandum on the removal of Lockhart River people', 23-25 October 1962.

34 Native affairs report', Q.P.P. 1960-1:1167, 1190; 1961-2:1353-5; 1962:1370, 1377-8; Craig 1980:79-80.

35 Taylor 1984:338-40. 


\section{ABORIGINAL HISTORY 1991 15:1}

dormitory system and the close supervision of girls and unmarried women although similar supervision existed at Palm Island. Yarrabah's education standards were poor even in comparison with the low standards expected and accepted on government reserves. ${ }^{36}$

Yet, there was a good deal of justification in Bishop Shevill's angry protest when the Minister for Aboriginal Affairs, Dr Noble, informed the press in 1959 that Yarrabah Mission 'lacks all facilities' 37 'Of course, we want housing, new school, a new hospital, and an airstrip. For these things we have been battling for seven years', the Bishop retorted. He pointed out that each year they had estimated the costs of servicing the community and each year their requests had been 'cut to the bone by the Government of Queensland'. By 1967 the Government's cheap ride at the expense of the Anglican Church and to the cruel detriment of the Aboriginal people was over.

By 1968, the post-missionary age had dawned for the Aborigines on ABM supported missions. The theological significance of that was probably lost on the Aborigines. One set of administrators who had been given authority over their communities was replaced by another, the Department of Aboriginal and Islander Affairs. The Anglican Church moved from its central role in the secular activities of each community, to which it had devoted such a great deal of its efforts, to the periphery. For many Aborigines the religious trappings of the mission years lost their significance. The move from mission to church meant that the senior advocate of culture change was now the government. Aborigines were keen to accept many innovations from the white intruders while wishing to maintain basic cultural values. As John Taylor said of the Edward River people, they bound themselves to Europeans 'in a culture-donor/culture-recipient relationship'. Once the missionaries withdrew from this central role, they tumed to the Department of Aboriginal and Islander Affairs. ${ }^{38}$

\section{BIBLIOGRAPHY}

Australian Board of Missions. Board Minutes, 1940-1970. ABM and Mitchell Library, Sydney.

. Chairman's Correspondence. ABM and Mitchell Library, Sydney.

. Budget '86. Sydney, 1986. . ABM 1984. Sydney, 1984.

Courier Mail, 25 August 1959.

Craig, Daniel. The social impact of the State on an Aboriginal reserve [Yarrabah] in Queensland, Australia. Ph.D.Thesis, University of California, Berkeley, 1980.

Diocese of Carpentaria Papers. Oxley Library, Brisbane.

Diocese of North Queensland. Yearbook. Townsville, 1959.

Green, Neville. The Oombulgurri story: a pictorial history of the people of Oombulgurri 1884-1988. Cottesloe, Western Australia, 1988.

Health and Home Affairs - In Letters, 6694 of 1961, Queensland State Archives, Brisbane.

Loos, Noel and Keast, Robyn. "The radical promise: the Aboriginal Christian co-operative movement', Australian Historical Studies. Forthcoming.

Partners. 'ABM Budget 1989', February-April 1990.

Queensland Parliamentary Papers. 'Native affairs report', 1950-1970.

Taylor, John Charles. Of acts and axes: an ethnography of socio-cultural change in an Aboriginal community [Edward River], Cape York Peninsula. Ph.D.Thesis, University of Queensland, 1984.

38 Taylor 1984:607. 


\section{THE QUEENSLAND GOVERNMENT TAKE-OVER OF ANGLICAN MISSIONS}

Interviews with Bishop Arthur Malcolm, Diocese of North Queensland, during 1988 and 1989 at Yarrabah and at Townsville, 10 November 1989.

Interview with Bishop A. Hall-Matthews, Diocese of Carpentaria, 18 March 1991.

Interview with Mr Fred Thompson, retired Amalgamated Engineering Union Organiser, 17 December 1990. Telephone. 